\title{
Assessing The Comparative Effectiveness Of Teaching Undergraduate Intermediate Accounting In The Online Classroom Format
}

Anne J. Rich, Central Connecticut State University, USA Mary I. Dereshiwsky, Northern Arizona University, USA

\begin{abstract}
This paper presents the results of a study assessing the comparative effectiveness of teaching an undergraduate intermediate accounting course in the online classroom format. Students in a large state university were offered an opportunity to complete the first course in intermediate accounting either online or on-campus. Students were required to complete several objective homework assignments and write an essay on what is means to be a professional. In addition, students were asked to report their progress in achieving seven stated objectives of the course. Students in the online course performed as well as students in the on-campus course.
\end{abstract}

Keywords: Intermediate Accounting; Online Education; Distance Education

\section{INTRODUCTION}

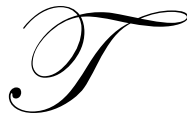

he academic community will quickly acknowledge the proliferation of online courses at the university level. Once delegated only to proprietary online programs, the ability to deliver traditional courses through the internet has radically changed the landscape of American college campuses. For the past seven years, the Babson Survey Research Group has tracked the state of online learning in U.S. higher education. In their latest report entitled" Learning on Demand: Online Education in the United States 2009" (Allen, 2010), the authors identify the following statistics related to the growth of online education:

- Online enrollments have continued to grow at rates far in excess of the total higher education student population, with the most recent data demonstrating no signs of slowing.

- Over 4.6 million students were taking at least one online course during the fall 2008 term, which represents a 17 percent increase over the number reported the previous year. The 17 percent growth rate for online enrollments far exceeds the 1.2 percent growth of the overall higher education student population.

- More than one in four higher education students now take at least one course online.

The report is often cited to support the overall effectiveness of online education at the higher education level. While administrators are usually supportive of expanding online courses, many college-level professors remain skeptical, preferring to believe that only traditional delivery of classes create effective learning environments. In the areas of accounting, there is only preliminary support for the effectiveness of both introductory and advanced accounting courses offered via the Web.

\section{PURPOSE OF THIS STUDY}

As accounting departments across traditional universities in the United States are deciding to expand their online course offerings, faculty are interested in the achievement of learning outcomes when courses are delivered through the internet. Currently, there are faculty who believe only face-to-face on-campus experiences can provide 
the proper learning environment for undergraduate accounting students. The purpose of this study is to report on the performance of students taking an intermediate accounting course online compared with students who took the course in the traditional on-campus format. Student assessments of learning included nine objective online homework problems and an essay on professionalism. In addition, students were surveyed to provide selfassessments of learning based on seven learning objectives for the course. If similar outcomes can be accomplished in online courses in students' achievement of learning objectives performance on homework, and in their understanding of professionalism, then accounting faculty will have more confidence in offering online courses as part of their academic programs.

\section{PRIOR RESEARCH ON THE EFFECTIVENESS OF ONLINE COURSES}

A substantial body of literature exists supporting the effectiveness of online courses at the university level. To answer the following question: Does taking a course via distance education lower a student's chances for success as compared to the same student taking the same course in a face-to-face format?, Thomas Russell has provided the academy with an annotated bibliography of research in his book, "The No Significant Difference Phenomenon: A Comparative Research Annotated Bibliography on Technology for Distance Education" (Russell, 2010) Another resource, published by the U.S. Department of Education and included more than 1,000 empirical studies of online learning, concluded that, "on average, students in online learning conditions performed better than those receiving face-to-face instruction." (Department of Education, 2009). However, Jaggars and Bailey (Jaggars, 2010) argued that, among other limitations, the report does not pertain to fully online, semester-length college courses. Indeed, as compared to the traditional face-to-face environment, there is some evidence to show that not all learners do as well in fully online courses. Furthermore, not all studies support distance learning as equal to the on-campus experience. Ferguson and Tryjankowksi, Ferguson (2009), for example, examined cognition, learning and assessment of performance of master's-level students in an online course and compared them with the performance of students in a face-to-face classroom setting of the same course. Students in the face-to-face class scored significantly higher on two out of the three measures.

While there is currently a proliferation of accounting courses in proprietary online programs, the Wall Street Journal reported in 2010 that three of the largest for-profit universities offering accounting online courses, the University of Phoenix, DeVry University, and Kaplan University, now have a total of almost 700,000 students enrolled in all of their programs. While there are far more accounting students enrolled in traditional on-campus accounting programs than entirely online programs, most accounting departments in campus environments have, nevertheless, not been eager to jump into offering online courses. There are some notable exceptions. To take advantage of the internet, a few universities, such as the University of Maryland University College and Quinnipiac University, have created separate units to provide online courses. Other universities, such as the University of Connecticut, offer a Masters of Accounting entirely online. Still, there are questions concerning the effectiveness of online courses. Early studies relating to accounting courses in brick-and- mortar environments were limited to introducing internet resources through programs such as Blackboard. One of these earlier studies that related to online accounting education was published by Larson-Birney (2000). The purpose of her case study was to determine the strengths and weaknesses of an introductory accounting course delivered entirely over the Internet. The author examined the following components: (1) the startup materials; (2) the Web-based course management system; (3) the computer-based instruction and textbook; (4) the structure of the course and attitudes it promoted toward online learning, computer-based instruction, and self-regulated learning traits; and (5) the structure of the course in order to support the kind of learning the students need to be successful by comparing the final exam grades, final course grades, and withdrawal rates of the Internet and non-Internet classes. The author's findings revealed that the students in the early years of internet delivery of courses were initially confused about how to begin the course, but as the course progressed students found the Web-based course easier to use. The final exam grades and final course grades were very similar between the two groups. However, the withdrawal rate was almost three times higher in the Internet class.

In another early study, Gagne and Shepard (Gagne, 2001) found the performance of students in a distance course was similar to the performance of students in the on-campus course for an introductory accounting graduate class. The authors used the multiple-choice exam format and the complex problem- solving exam format to assess student performance. The authors also looked at the results of students' evaluations and also found similar results 
for both online and face-to-face learners. However, online learners were significantly less satisfied with instructor availability than their face-to-face student counterparts.

One major obstacle with online courses is the limited ability to administer exams to students in a classroom environment. Online students can be anywhere in the world. They often take the class because they are unable to come to a brick-and-mortar campus. As a result, online courses tend to utilize more multiple- choice tests. As online accounting courses expanded across universities, one issue that required the attention of researchers was the mode of testing. Hun and his colleagues (Hun, 2008)) compared the performance of students in online and offline accounting courses during the Fall 2003 through Spring 2005 period to see if there was any difference in the performance between accounting students who were on-line learners and accounting students who were on campus- Their results suggested that there are no significant differences in testing performances such as total scores, multiple scores, and non-multiple choice scores between online learners and offline learners. In another study Huh (2010) and his colleagues examined the effects of student characteristics on performances as measured by test scores. The second purpose of Hun's research study was to investigate if there is any systematic difference in those effects between online courses and offline courses. Overall, their results indicated that while there is no significant difference in student performances, some characteristics or variables have differential effects on performances for online and offline learners. Specifically, the effects of GPA and gender on performances were significantly higher for offline students than for online students.

Even as late as 2009, accounting instructors were for the most part simply integrating a computer component into their courses. Walters and Robertson (Watters, 2009) looked at student perceptions to assess the effectiveness of an online component of traditional accounting courses. The authors reported the results of a survey of introductory and advanced accounting students where an internet component was integrated into their courses. Students in the three courses could access the archived video presentations over the Internet or burn the presentations to a $\mathrm{CD}$ or a flash memory drive, thus allowing them to view the digital videos at any time and as many times as desired. Students in the undergraduate courses were slightly less enthusiastic about online delivery; overall, approximately $75 \%$ of such students indicated that the online delivery of the courses was as effective, or more effective, than a traditional course.

Research that focuses on the effectiveness of online courses has its challenges. Often there are compounding elements such as one teacher teaching the online course while a different instructor teaches the oncampus course. In addition, the types of assessments are often different between online and on-campus courses. Online courses tend to use more objective-type homework, quizzes and exams as part of student performance assessment. Finally, student assessment of online courses may be affected by the availability and quality of technical support as well as other technical issues that online learners experience and that their on-campus counterparts do not face.

\section{THE RESEARCH STUDY}

The authors were interested in determining the effectiveness of an entirely online accounting course as compared with an on-campus course. One of the authors was allowed to develop an online intermediate accounting course. It was delivered for the first time in the spring of 2010 at Central Connecticut State University (CCSU). CCSU is a large urban university. The program requires what many universities would identify as a bridge course called Foundations of Accounting (AC 300). This course covers the introductory chapters in an intermediate accounting text. The course also includes assignments related to professional ethics, research on the internet and financial analysis.

In the spring of 2010, four sections of AC 300, Foundations of Accounting, were offered at Central Connecticut State University. This course requires six credits of principles of financial and managerial accounting. One of the sections was delivered as an online course. Two sections were offered during the day. The fourth section was offered during the evening. One instructor taught the day and online sections while a second instructor taught the evening section. Table 1 displays summary descriptive statistics (totals and percentages) of those students who responded. 
Table 1: Summary Descriptive Statistics of Study Sample

\begin{tabular}{|l|c|c|c|c|c|}
\hline Section & $\begin{array}{c}\text { No. of students } \\
\text { registered }\end{array}$ & $\begin{array}{c}\text { Number of full } \\
\text { time students }\end{array}$ & $\begin{array}{c}\text { Number of } \\
\text { Accounting Majors }\end{array}$ & $\begin{array}{c}\text { Number with full } \\
\text { time jobs }\end{array}$ & $\begin{array}{c}\text { Number of } \\
\text { students age 18-22 }\end{array}$ \\
\hline Online & 19 & $10(77 \%)$ & $8(62 \%)$ & $8(62 \%)$ & $4(30 \%)$ \\
\hline Day & 52 & $43(97 \%)$ & $38(86 \%)$ & $7(15 \%)$ & $32(72 \%)$ \\
\hline Evening & 30 & $15(51 \%)$ & $23(79 \%)$ & $16(55 \%)$ & $9(31 \%)$ \\
\hline
\end{tabular}

Students who registered for the online course were more typical of the evening section. The age of the both the evening students and the online students tended to be more than 22 years old. In addition, both the evening students and the online students had full-time jobs. However, the online course attracted more non-accounting majors, perhaps because the non-accounting majors needed an elective to complete their requirements for graduation. Students in all sections met the prerequisite of six credits of introductory accounting courses. The course objectives are:

1. To understand the ethics of the accounting profession and its role in society

2. To understand the skills necessary to be successful in accounting positions

3. To be familiar with the Financial Accounting Standard Board's (FASB) Conceptual Frame work and the authoritative standard-setting agencies

4. To be able to complete the accounting cycle from recording entries, making adjustments and generating a trial balance

5. To be able to prepare basic financial statements in good form

6. To perform basic financial statement analysis

7. To draw conclusions after performing a financial analysis of a company

Requirements of the course included the following:

1. Discussion of ethical case studies

2. Research of major accounting scandals

3. Research of major accounting websites

4. Completion of an computerized practice set

5. Homework problems submitted through the publisher's website homework manager program

6. Financial analysis of a public company

7. Submission of an essay on what is means to be a professional

In order to obtain measures of the effectiveness of the online course, the following items were utilized in the assessment of the online intermediate accounting course:

1. Objective scores on nine sets of homework problems submitted to the publisher's website for grading.

2. Results of a survey reporting students' perceptions of their improvement in knowledge relating to the seven objectives of the course.

3. Results of grading by the instructors of an essay on what it means to be a professional. A rubric was created to assess students' success.

\section{ASSESSMENT RESULTS}

\section{Objective Homework}

Objective assessments of the effectiveness on the online course are seen in the scores on homework assignments. One instructor selected all of the exercises and problems to be completed by all students. In most cases, the program provided each student with a unique data set. The program also provided some additional features such as drop- down boxes. Students also were allowed to submit their answers twice. There were two homework assignments related to the accounting cycle, one related to the FASB's conceptual frame work, two on the income statement, two on the balance sheet, and two on the cash flow statement. The last assignment integrated both the 
cash flow and balance sheet concepts. The homework scores are reported for all students in the class. The results in Table 2 demonstrate no significant differences, with one exception. There was a difference on the objective homework assignments for one of the topics covered in the course. Students in the evening section appeared to perform better on the last topic covered, cash flow, than either the day or online students. However, the online students performed as well as the day students on all topics.

Table 2 - Scores On Nine Homework Problems Graded By The Publisher's Software Program

\begin{tabular}{|c|c|c|c|c|c|c|c|c|c|c|c|}
\hline & No. of stud & dents & $\begin{array}{l}\text { Accounting } \\
\text { Cycle }\end{array}$ & $\begin{array}{l}\text { Accounti } \\
\text { ng Cycle }\end{array}$ & $\begin{array}{l}\text { Conceptual } \\
\text { Framework }\end{array}$ & $\begin{array}{l}\text { Income } \\
\text { Statement. }\end{array}$ & $\begin{array}{l}\text { Income } \\
\text { Statement }\end{array}$ & $\begin{array}{l}\text { Balance } \\
\text { Sheet }\end{array}$ & $\begin{array}{l}\text { Balance } \\
\text { Sheet }\end{array}$ & $\begin{array}{l}\text { Cash } \\
\text { Flow }\end{array}$ & $\begin{array}{l}\text { BS and } \\
\text { Cash } \\
\text { flow }\end{array}$ \\
\hline Day 1 & 25 & & 90 & 98 & 87 & 80 & 82 & 98 & 90 & 74 & 85 \\
\hline Day 2 & 27 & & 83 & 96 & 87 & 80 & 85 & 99 & 94 & 71 & 85 \\
\hline Online & 19 & & 84 & 94 & 87 & 83 & 85 & 99 & 89 & 71 & 85 \\
\hline Evening & 30 & & 93 & 94 & 88 & 85 & 82 & 99 & 91 & 86 & 96 \\
\hline total & 101 & Average & 88 & 96 & 87 & 82 & 84 & 99 & 91 & 76 & 88 \\
\hline & & & & & & & & & & & \\
\hline
\end{tabular}

\section{Self-reported Improvement}

At the conclusion of the course, students were surveyed to assess their perceptions of their growth towards the seven course objectives. Students were asked to identify, on a scale of $1-7$ (7 being the highest), their knowledge at the beginning of the course and again at the conclusion of the course. The seven learning objectives were:

1. To understand the accounting profession and its role in society

2. To understand the skills necessary to be successful in accounting positions

3. To be familiar with the FASB's Conceptual Frame work and the authoritative standard-setting agencies

4. To be able to complete the accounting cycle from recording entries, making adjustments and generating a trial balance

5. To be able to prepare basic financial statements in good form

6. To perform basic financial statement analysis

7. To draw conclusions after performing a financial analysis of a company

\section{Statistical Analysis of Self-reported Improvement}

To determine if there was a statistical difference among the three classes, the data were analyzed using PASW statistical analysis software (formerly known as SPSS). The Kruskal-Wallis non-parametric test was used to assess mean rank differences among the groups. The mean changes in ranks were compared by "format of classroom," coded as online (1), day (2), or evening (3). Table 3 provides the mean ranks in self-reported change scores related to the seven course learning objectives. Table 4 displays the results of the analysis. There were no statistically significant differences in mean rank change scores for any of the survey items by "format of classroom." 
Table 3: Mean Ranks In Self-Reported Change Scores Related To The Seven Course Learning Objectives Sub-grouped by "Classroom Format

\begin{tabular}{|c|c|c|c|}
\hline Learning objective & Course format & $\mathbf{N}$ & Mean Rank \\
\hline \multirow[t]{4}{*}{ Changeskills } & 1 online & 12 & 37.88 \\
\hline & 2 day & 44 & 48.35 \\
\hline & 3 evening & 29 & 37.00 \\
\hline & Total & 85 & \\
\hline \multirow[t]{4}{*}{ ChangeFASB } & 1 online & 12 & 44.92 \\
\hline & 2 day & 44 & 43.43 \\
\hline & 3 evening & 29 & 41.55 \\
\hline & Total & 85 & \\
\hline \multirow[t]{4}{*}{ Changecycle } & 1online & 12 & 37.42 \\
\hline & 2 day & 44 & 44.51 \\
\hline & 3 evening & 29 & 43.02 \\
\hline & Total & 85 & \\
\hline \multirow[t]{4}{*}{ Changebasic } & 1online & 11 & 28.23 \\
\hline & 2 day & 44 & 43.50 \\
\hline & 3 evening & 29 & 46.40 \\
\hline & Total & 84 & \\
\hline \multirow[t]{4}{*}{ Changeanalysis } & 1online & 12 & 32.00 \\
\hline & 2 day & 44 & 45.18 \\
\hline & 3 evening & 29 & 44.24 \\
\hline & Total & 85 & \\
\hline \multirow[t]{4}{*}{ Changeconclusion } & 1 online & 12 & 35.17 \\
\hline & 2 day & 44 & 45.13 \\
\hline & 3 evening & 29 & 43.02 \\
\hline & Total & 85 & \\
\hline \multirow[t]{4}{*}{ Changeprofrole } & 1 online & 11 & 38.68 \\
\hline & 2 day & 44 & 45.16 \\
\hline & 3 evening & 29 & 39.91 \\
\hline & Total & 84 & \\
\hline
\end{tabular}


Table 4: Kruskal-Wallis Test Results

Sub-grouped by "Classroom Format"

\begin{tabular}{|l|c|c|c|c|c|c|c|}
\hline Test Statistics & $\begin{array}{c}\text { Change } \\
\text { skills }\end{array}$ & $\begin{array}{c}\text { Change } \\
\text { FASB }\end{array}$ & $\begin{array}{c}\text { Change } \\
\text { Cycle }\end{array}$ & $\begin{array}{c}\text { Change } \\
\text { Basic }\end{array}$ & $\begin{array}{c}\text { Change } \\
\text { Analysis }\end{array}$ & $\begin{array}{c}\text { Change } \\
\text { Conclusion }\end{array}$ & $\begin{array}{c}\text { Change } \\
\text { Profrole }\end{array}$ \\
\hline Chi-square & 4.508 & .191 & .808 & 4.739 & 2.881 & 1.578 & 1.171 \\
\hline & & & & & & & \\
\hline df & 2 & 2 & 2 & 2 & 2 & 2 & 2 \\
\hline Asymp. Sig. & .105 & .909 & .668 & .094 & .237 & .454 & .557 \\
\hline
\end{tabular}

a. Kruskal Wallis Test

b. Grouping Variable: AC 300 Spring 2010

1 online, 2 day, 3 evening

As can be seen in the results reported in Tables 3 and 4, there were no statistically significant differences in mean rank change scores for any of the survey items by "format of classroom."

\section{Assessment of Professionalism}

AC 300, Foundations of Accounting, was selected by the Department of Accounting at Central Connecticut State University to communicate the importance of professionalism. Several characteristics of being a professional were identified. They included the following qualities:

- $\quad$ Follows a code of ethics/exercises high ethical standards

- $\quad$ Presents a professional demeanor/dress

- $\quad$ Uses professional communication (memos, speaking, email)

- $\quad$ Is responsible - completing work on time; contributing to team work

- Is competent - meets educational standards, knowledgeable, being expert

- $\quad$ Exercises due care, makes full disclosure

During the semester, students discussed cases dealing with ethical dilemmas; they researched accounting scandals and discussed current events. To assess their understanding of what is means to be a professional accountant, students were asked to write a short essay. They were provided with the following directions:

This course focused on professionalism. Write 2- 3 paragraphs on what you learned about what it means to be a professional. Identify at least 3 characteristics that reflect professionalism in the accounting profession.

\section{The Essay on Professionalism Results}

In the spring of 2010, there were four sections of AC 300. Two day sections and one online section were taught by the full-time professor who developed the syllabus and one evening section was taught by an adjunct professor. Table 5 shows the results of the students' scores, using a grading rubric, on an essay describing characteristics of being a professional.

Table 5: Summary Descriptive Statistics of Performance Level of Students Who Completed Essay Requirement

\begin{tabular}{|l|c|c|c|c|}
\hline \multicolumn{1}{|c|}{ Section } & $\begin{array}{c}\text { Students completing } \\
\text { requirement }\end{array}$ & $\begin{array}{c}\text { Percentage of students } \\
\text { who achieved } \\
\text { outstanding/meets } \\
\text { expectations }\end{array}$ & $\begin{array}{c}\text { Percentage of students } \\
\text { who achieved } \\
\text { satisfactory }\end{array}$ & $\begin{array}{c}\text { Percentage of } \\
\text { students who were } \\
\text { unsatisfactory }\end{array}$ \\
\hline AC300-01 and 02 & 52 & $87 \%$ & $13 \%$ & - \\
\hline AC300- CO 1 online & 18 & $94 \%$ & $6 \%$ & - \\
\hline Ac 300-70 & 34 & $74 \%$ & $20 \%$ & $6 \%$ \\
\hline Total & 104 & & & \\
\hline
\end{tabular}


The instructors identified students' responses as meets expectations if the essay included at least three of the listed desirable characteristics. Students scored satisfactory if they identified two of the desirable characteristics. Unsatisfactory scores were assigned to students who were only able to identify one or none of the listed characteristics. The results shown in Table 5 reveal that online students actually performed better overall than the day or evening students on their ability to identify professional characteristics.

\section{DISCUSSION OF RESULTS OF THIS STUDY}

In this study, one teacher taught three sections of an intermediate accounting course. A second teacher taught the evening on-campus section. The day sections were typical full-time students under the age of 22. The online and evening sections were attended by both full-time and part-time students who tended to be from an older population. The evening and online sections had more part-time learners with work experience. All but two students were able to enter the class format of their first choice. The research objective was to assess if onlinelearners demonstrated similar outcomes in achieving the objectives of the course. Performance measures included the following: (1) problem-type homework problems delivered online through the publisher's website and were by the computer program and (2) an essay on professionalism graded by the instructor and (3) students' self-reported progress towards seven course objectives. The results clearly show that for all of the assessments, the students enrolled in the online intermediate accounting course achieved similar results to those of the students enrolled in the on-campus intermediate accounting course.

\section{LIMITATIONS OF THE STUDY}

In this study, students were able to self-select the type of delivery system for the course. Students in the online course had similar demographics to those in the evening program. These students tended to be older and had more work experience. Students who take online courses need to have excellent time-management skills. If students were randomly assigned to the online and on-campus sections, there may be different outcomes. Learning styles were not considered in the analysis. Some students may do better in the face-to-face classroom environment because they are more comfortable with this type of interaction. The online instructor in this study possessed significant online course experience. Less experienced faculty may not have achieved the same result. The skills, abilities and interest of the instructor may also have an impact on student satisfaction and learning. Finally, the type of performance measures used to evaluate the effectiveness of the course may impact the results. In this study, only the objective homework problems and the essay on professionalism were selected for analysis. The homework problems were selected from the publisher's website. The scoring of homework problems was accomplished by the computer program available from the same publisher's website. If different types of problems were selected or if homework was graded by a different program or manually, the results may be different. Similarly, if different assessments were used, the results may not be the same. For both the online as well as on-campus sections, there were no controls to assure that students submitted their own work. In addition, there is the possibility that students who completed the assignment at home did not submit their own original work.

\section{AREAS FOR FUTURE RESEARCH}

Online courses are now being offered by most universities. As a result, it is now possible to research the impact of student characteristics as well as faculty expertise and the support environment relating to the success of student learning. In this study, students from one university were able to select between an online course and an oncampus course. Future research should examine the impact of the students' learning styles, maturity, timemanagement skills, and experience in participating in online courses on the ability of students to be successful in online courses. In addition, the experience of the instructor may have a significant impact on the delivery of an online course. Finally the technical support provided by the university may also impact the overall learning experience of the student. 


\section{CONCLUSION}

Students who enter college today have been exposed to the computer all of their lives. Many are comfortable with online learning. While some students may prefer the on-campus experience, others either prefer online learning or are limited to this delivery system. Some accounting faculty have been reluctant to offer online courses. All professors are understandably concerned about students submitting their own work. In the online environment, no one can guarantee that a student has submitted original work. For faculty who feel that the biggest obstacle to delivering intermediate accounting in an online format is related to whether or not students are able to learn intermediate accounting concepts in an online format, this study provides evidence that similar outcomes are possible. Students who are able to self-select the delivery system for an intermediate accounting course, who are taught by an instructor who is comfortable with technology, and are supported by a university that provides adequate technological support, are likely to experience a beneficial learning environment similar to that of students in a traditional campus environment.

\section{AUTHOR INFORMATION}

Anne Rich, Ph.D., CPA, CMA is professor of accounting at Central Connecticut State University. E-mail: richann@ccsu.edu

Mary I. Dereshiwsky is professor of educational leadership and research at Northern Arizona University. Both authors have extensive experience in developing and teaching online courses at the university level. E-mail: Mary.Dereshiwsky@nau.edu

\section{REFERENCES}

1. Allen, I. E. (2010). Learning on demand: Online education in the United States. Massachusetts: Babson Survey Group.

2. Department of Education. (2009). Evaluation of evidence-based practices in online learning: A metaanalysis and review of online learning studies. Washington, DC.

3. Ferguson, J. (2009). Online versus face-to-face learning: looking at modes of instruction in master's-level courses, Journal of Further and Higher Education, 33 (3), 219-228

4. $\quad$ For-profit Kaplan U. hears its fight song, Wall Street Journal, August 30, 2010.

5. Gagne, M. (2001). Distance learning in accounting: A comparison between a distance and traditional graduate accounting class. T.H.E. Journal, 58-65. retrieved from http://nosignificantdifference.wcet.info/faq.asp.

6. Huh, S., Jin, J., Lee, K., \& Yoo, S. (2010). Differential effects of student characteristics on performance: online vis-a-vis offline accounting courses. Academy of Educational Leadership Journal, 14(4), 81-89. Retrieved April 4, 2011, from ABI/INFORM Global. (Document ID: 2185718691).

7. Huh, S., Yoo, S., Jin, J., \& Lee, K.. (2008). Comparisons of performances between online learners and offline learners across different types of tests. Academy of Information and Management Sciences Journal, 11(1), 45-63. Retrieved April 4, 2011, from ABI/INFORM Global. (Document ID: 1778514341).

8. Jaggars, S. S., \& Bailey, T. (2010). Effectiveness of fully online courses for college students: Response to a Department of Education meta-analysis. New York, NY: Columbia University, Teachers College, Community College Research Center.

9. Larson-Birney, Brenda (2000). Evaluation case study of an introductory accounting course taught over the Internet using computer-based instruction. Ed.D. dissertation, Northern Arizona University, United States - Arizona. Retrieved April 4, 2011, from ABI/INFORM Global.(Publication No. AAT 9989711).

10. Russlell, T. L. (2010). No significant difference. Retrieved July 25 2010, from http://nosignificantdifference.wcet.info/faq.asp

11. Watters, M. P. \& Robertson, P. (2009). Online delivery of accounting courses: Student perceptions, Academy of Educational Leadership, 13(3), 51-58. 
NOTES 